\title{
The Influence of Passion towards Critical Thinking Disposition among Athletes in University
}

\author{
Tajularipin Sulaiman (PhD) a, b
}

Corresponding author, tajulas@upm.edu.my

Azlida Mohamad (MSc) a, b

sayaidamohamad@gmail.com

Roselan Baki (PhD) a, b

ros_baki@upm.edu.my

\section{Borhannudin Abdullah (PhD) ${ }^{b}$}

borhannudin@upm.edu.my

a Sports Academy, ${ }^{b}$ Faculty of Educational Studies, Universiti Putra Malaysia, 43400 Serdang, Selangor, Malaysia

\section{Doi:10.5901/mjss.2015.v6n2p569}

\section{Abstract}

Passion is a real strength enabling individuals go to action and achieve great things. Many glories of discoveries and achievements were only reached due to enthusiasm and the perseverance that characterize passionate behavior. Critical thinking disposition is essential affective component of critical thinking skills that really beneficial in growth of cognitive knowledge. The purpose of this study was to investigate the influence of passion towards critical thinking disposition among athletes in higher education. The study employs a correlational research design by using survey procedures. A questionnaire composes passion items and critical thinking disposition items were used to collect the data. T- Test was employed to compute the mean in order to identify the significant differences on passion and critical thinking disposition construct between technical and social science fields. Results showed that there was only significant difference on passion in sport but not in critical thinking disposition construct. The multiple regression analysis indicated that harmonious passion weakly influenced critical thinking disposition (Adj. R Square= .052) and most of its subscales. Based on the findings, researcher concludes that harmonious passion towards sport has an impact on critical thinking disposition. More research is needed to concern on critical thinking development underlying harmonious passion among national athletes.

Keywords: Passion; Harmonious Passion; Obsessive Passion; Critical Thinking Disposition; Athlete; Higher Education

\section{Introduction}

Passion is about the concept of desire. This term refers to a strong inclination towards an activity that individuals like or even love, that they value, and in which they invest time and energy (Vallerand, Blanchard, Mageau, Koestner, Ratella, \& Leonard, 2003). The conceptualization of passion represents an essential determinant of active involvement in activities that people like and they care about. Passion appears as a motivational force underlying engagement in practice and robust predictor of performance in sports (Vallerand, Mageau, Elliot, Dumais, Demers, \& Rousseau, 2008). Passion can be categorized into two types, harmonious passion and obsessive passion. Meanwhile, critical thinking disposition is a consistent internal motivation to use critical thinking skill to decide what to believe and what to do. Critical thinking disposition was measured by seven subscales such as analyticity, open-mindedness, inquisitiveness, CT self-confidence, truth-seeking, systematic and maturity. The integration of critical thinking disposition and skill in athletes is vital to provide intellectual challenges and relevant learning experiences, as well as enhance the quality of performance in sport activity that involved. In order for critical thinking to be mastered and become extremely efficient, some driven value like passion cannot be neglected. Therefore, this study was essential to investigate the effect of passion in sport towards critical thinking disposition among athletes in higher education. In order to know the influence of passion in sport towards critical 
thinking disposition, the researchers had first analyzed the data to find out the presence of correlation. Researchers also identified the significant differences on both constructs with respect to the respondents fields of study.

\section{Literature Review}

\subsection{Passion in sport}

Passion is a very strong feeling about a person or thing. It refers to a strong inclination towards an activity that people like, find important and in which they invest time and energy (Vallerand \& Houlfort, 2003; Vallerand \& Miquelon, 2007). When individuals are passionate, their view of life is driven by positive affectivity (Balon, Lecoq, \& Rimé, 2013). Consequently, they tend to give their best and to surpass goals. However, if a person just loves and invests time in an activity, but does not value it, the activity just can be reflected as being intrinsically motivating not a passion yet. Athletes who are passionate will fully dedicate themselves to their sport and continuously persevere in facing obstacles and to eventually reach excellence (Vallerand et al., 2008). When an athlete is passionate about their goals, they tend to be less obsessive about their behavior while on game, resulting in achieving higher performance and more task satisfaction. Vallerand et al. (2008) viewed passion was to be a catalyst which is providing the energy for persistent and strategic engagement in sport activity. He also mentioned a passion becomes a central feature of one's identity. Such an individual passionate to playing netball, she does not merely play netball but she is "netball player". As stated by Linstead and Brewis (2007), "passion is an intense, driving, or overmastering feeling or conviction". This suggests that passion is a vivid emotional attachment which can be positive or negative.

Passion can be classified into two types which are harmonious passion and obsessive passion (Vallerand et al., 2008; Parastatidou, 2012). The harmonious passion occurs when one without attaching contingencies is free to choose to engage in any activity (Vallerand, Blanchard, Mageau, Koestner, Ratella, \& Leonardet, 2003; Vallerand et al., 2008). They find an intrinsic joy in their doings. For instance, netball players, they play just because of the joy it brings to them. They have a sense of control towards passion and expect no extra gain when doing the activity other than pleasuring themselves (Vallerand et al., 2003). According to Vallerand et al. (2008), harmonious passion is hypothesized in facilitating control over the activity and contributing to the experience of positive effect. The second type of passion is obsessive passion. Obsessive passion produced when an individual engages in a beloved activity, then experiences internal pressure or has uncontrollable clinging towards it (Vallerand et al., 2003). Some people are fully attached to the passion which will derive their sense of self from the act of being passionate. It is because they have an uncontrollable urge to engage in their obsession. Furthermore, obsessive passion an internal compulsion leads the person to engage in the activity even when they should not or they may experience negative emotions once engagement in the passionate activity is terminated.

\subsection{Critical thinking disposition}

Critical thinking has existed since the ancient Greece over 2500 years ago by Socrates, the pioneer of critical thinking (Irfaner, 2006; Rozgay-Miller, 2009). Critical thinking is in the family of higher order thinking skills, along with creative thinking, problem solving and decision making (Facione, 1990; Som \& Mohd Dahalan, 1998). Word "critical" means to understand the people and things around us and analyses our own thinking processes (Emir, 2009).

Critical thinking includes critical thinking skill and critical thinking disposition (Siegel, 1988; Facione, 1990; Qing, Ni, \& Hong, 2010). This view was proven in early research which is a more significant outlook of critical thinking must contain the acknowledgement of a characterological aspect called as a disposition. The disposition toward critical thinking focuses to the likelihood that one will approach or solve problem by using reasoning (Giancarlo \& Facione, 2001). Also, Facione (2000) defined the word "dispositions" as characterological attributes of individuals. He characterized the disposition toward critical thinking as the consistent internal motivation to use critical thinking skills to decide what to believe and what to do (Facione, 1997, 2000; Profetto, 2003; Zhang, 2003). Similarly, early researcher, Dewey (1933) viewed the dispositional components of thinking as "personal attributes".

Overall critical thinking disposition emerged in seven aspects of disposition. Profetto-McGrath (2003) expressed critical thinking disposition as being analytical, open-minded, seeking the necessary, being systematic, self-confident, inquisitive and mature. These seven characterological attributes were similarly proposed by Facione and Facione (1992). Basically, the definition of critical thinking was more concern on cognitive level of learners rather than athletes but athletes are learners too.

According to Facione $(1995,2000)$ and Qing et al. (2010), truth-seeking is an attribute used to measure 
courageous desire ultimate knowledge and understanding of any given condition, the tendency to ask tough questions and to be willing to follow the evidence where ever they may lead even if the outcome is opposing to one's own preconceptions. Open-mindedness is the tendency to allow others to voice views with which one disagrees. An athlete who disposes the open- mindedness attribute inclines to tolerance toward the opinions of others players or coach. Analyticity emphasizes the application of reasoning and the use of evidence to solve problems, anticipating practical difficulties, and consistently being alert to the need to intervene by proving with reason and evidence to settle down problems (Facione, Giancarlo, Facione \& Gainen, 1995; Qing et al., 2010). Facione (2000) defined systematic as the habit of striving to approach problems in a disciplined, orderly and systematic manner. The player who is systematic may not know of a given approach, or may not be skilled at using a given game tactic, but he has concern in struggling to approach that strategy in an organized way. CT self-confidence measures trust in one's own reasoning and one's ability to guide others to make reasoned solutions (Facione et al., 1995). In the sport arena, an athlete has the obligation to instill confidence within himself and also his teammates and ultimately perform in a game. Inquisitiveness functions to measure intellectual curiosity in acquiring new knowledge and the intention to learn things even if their immediate application is not apparent yet (Facione et al., 1995). Maturity aspect measures the judicious in one's decision-making (Qing et al., 2010).

Some people may accept different views from others while some may not. Some are confident in their sport skills, but others tend to be in doubt. These diverse characters conclude that people might tend to be positive, negative or ambivalent disposed with regards to critical thinking. Theorists view that skill in critical thinking is positively correlated with the consistent internal motivation to think and that specific critical thinking skills are matched with specific critical thinking dispositions (Facione, 2000). However, those who are skillful in cognitive thinking are not necessarily good in intrinsic motivation to be able to apply that kind of thinking (Facione, 2000).

\subsection{Passion and critical thinking disposition in sport}

Early research referred to passion as a trait or at least something resulting from an individual's internal dispositions (Ribot, 1907 in Balon et al., 2013). However, recently, the concept of passion has reappeared in the psychological literature and known as a motivational strength (Balon et al., 2013). Deci and Ryan (2000) proposed the concept of passion has some similarity with the concept of intrinsic and extrinsic motivation, as both involve interest and liking toward the activity. As mentioned above, the disposition toward critical thinking also was referred as the consistent internal motivation to use critical thinking skills to decide what to believe and what to do (Facione, 1997, 2000; Profetto, 2003; Zhang, 2003). Base on the literature, there is a need to further investigate the correlation between passion and critical thinking disposition.

A very strong passion can potentially be a form of motivation towards positive disposition. As mentioned earlier, passion was to be a catalyst which is providing the energy for persistent and strategic engagement in sport activity (Vallerand et al., 2008). A controllable passionate person is willing to sacrifice time and energy to do something they are enthusiast about including being involved in critical thinking on the current matter. Hence, this present study want to expose the relation between passion and critical thinking disposition association to lead in achieving goal in sport. Another essential characteristic of passion is the activity and feeling has been internalized into one's identity. In the process, some of the activities could be so self-defining that they represent central features of one's identity (Vallerand, 2008).

Critical thinking encouraged athlete to clarify the misconceptions, discover half-truths, ravel out preposterous beliefs, look into self-contradictory attitudes, and size up poor evidence (Edmonds, Hull, Janik, \& Rylance, 2005). Meanwhile, Halpern (1998) stressed the dispositional aspect of thinking was refers to whether individuals have developed their reflective habits. One example in describing someone in terms of their dispositions which express the person's habitual ways of acting is a netball player who might be offensive-minded (likely to attack with the intent of scoring goals) or defensive-minded (likely to fall back with the intent of preventing the opponents from scoring) in her style of game play (Facione, 2000).

In order for critical thinking process to be developed and strengthened, the behavior patterns which parallel with skills throughout the day must be covered by the athlete. The integration of critical thinking skills into the athlete is vital to afford intellectual challenges and significant learning experiences to them. 


\section{Research Methodology}

\subsection{Participants}

The study employs a correlational research design by using survey procedures in order to investigate the influence of passion towards critical thinking disposition among athletes. A random sampling of 187 respondents was carried out. The respondents in this study were athletes studying in local universities around Malaysia. Data were collected in two stages; first, during an inter-university "Netball League" and second, through a sport meeting. Both events were held in the State of Selangor, Malaysia and were hosted by Universiti Putra Malaysia. Respondents were required to answer questionnaires during both stages of data collection. The first data collection stage was conducted through the 'drop-andpick-up-later' technique. Each team manager was given two days to distribute and collect questionnaires back from the athletes. For the second data collection, a committee member during a sport meeting was given the questionnaire to be distributed to the athletes.

\subsection{Instrument}

The instrument consisted of three sections and 12 questions and 68 items. First section was demographic information, second was passion in sport and the last section is thinking strategies. Demographic information (12 questions) focuses on respondent's personal and academic background. This data provides information for the structure of the respondent's profile that will be useful in interpreting data collected. There are two constructs involve in the study, passion in sport and critical thinking disposition. For section B (passion in sport), the original items were constructing by Vallerand et al. (2003). Their item widely used by past studies to measure passion in sport performance and has been found to display high level validity and reliability (Mageau et al., 2005 \& Ratella et al., 2004 in Donahue, Rip, \& Vallerand, 2009). This fact encourages researchers to pick the items directly without any modification. In addition, Vallerand (2010) explained passion scale has high levels of internal consistency as well as predictive, discriminant, construct and external validity. This section comprises 22 items include harmonious passion subscale and obsessive passion subscale.

For section C (thinking strategies), items was adapted from a research by Ibrahim, Kamariah, Nor Hayati, and Othman (2013). Through their factor analysis, value $>.70$ of factor loading was obtained and resulting to high construct validity for critical thinking disposition instrument. However, the original instrument focused on university student instead of athlete, therefore with his permission, researhers were slightly change some items to in line with current respondents. In addition, researchers elect two experts to review and validate items to ensure the instrument have high level of validity. The critical thinking disposition scales which consists of 46 items (7 subscales) is aim to measure the level of critical thinking toward disposition among athletes. The subscales include analyticity, open-mindedness, inquisitiveness, selfconfidence, truth-seeking, systematic and maturity. A five-point Likert-like scale ranging from $1=$ strongly disagree to $5=$ strongly agree was used in the questionnaire of the study (section B and section C). All items were refined through validity and reliability to ensure they comply with the purpose of the study and research samples. Pilot study with 50 respondents yielded coefficient alpha for the passion in sport and critical thinking disposition respectively with high reliability value, .896 and .872 .

Statistical Package of Social Science (SPSS) version 21.0 was used to analyze data obtained in the study. The researcher used independent T-test to differentiate the mean on passion in sport and critical thinking disposition between technical and social science field. In order to measure the significant relationships between passion in sport and critical thinking disposition, Pearson's Product Moment of Correlation was conducted. Then, regression analysis was executed to identify the influence percentage of passion in sport towards critical thinking disposition.

\section{Findings and Discussion}

\subsection{T-test on passion in sport based on fields of study}

Table 1 described the mean differences of variable passion in sport for the respective data of respondents according to two fields of study; technical science and social science. Based on the profile of demographic information, eighty eight respondents $(n=88)$ were from technical science field and ninety nine $(n=99)$ were from social science field. There was a significant difference for passion (overall) in sport between both fields $(t=-2.523, p<.05)$ as shown in Table 1 . The result indicated respondents in social science's field were more passionate in doing sport activity compared to technical science respondents. This study showed that the passion in doing sport activity among social science respondents were stronger 
compared to technical science respondents. The result indicated that the social science respondents are more passionate towards sport activities. The social science respondents tend to be obsessively passionate compared to the technical science respondents during their involvement in sport with significant difference $(t=-2.720, p<.01)$. Harmonious passion gave insignificant difference results between social science respondents and technical science respondets, $\mathrm{t}=$ $1.462, p>0.5$.

Table 1: Independent-sample-T-test on passion in sport scales based on fields of study

\begin{tabular}{|c|c|c|c|c|c|c|}
\hline \multirow{2}{*}{ Passion Subscales } & \multicolumn{2}{|c|}{ Technical Science } & \multicolumn{2}{|c|}{ Social Science } & \multirow{2}{*}{$t$} & \multirow{2}{*}{$p$} \\
\hline & Mean & S.D. & Mean & S.D. & & \\
\hline Harmonious passion & 28.84 & 4.149 & 29.67 & 3.571 & -1.462 & .145 \\
\hline Obsessive passion & 34.01 & 7.946 & 36.93 & 6.718 & -2.720 & $.007^{\star *}$ \\
\hline Passion (overall) & 83.17 & 11.739 & 87.31 & 10.710 & -2.523 & $.012^{\star}$ \\
\hline
\end{tabular}

${ }^{\star} p<.05,{ }^{* \star} p<.01$

\subsection{T-test on critical thinking disposition based on fields of study}

Table 2 described the mean differences of variable critical thinking disposition for the respective data of respondents based on two fields of study; technical science and social science. There was no significant difference between both fields in seven scales in critical thinking disposition. Based on the result, respondents from neither technical nor social science field showed no difference in their level of critical thinking disposition. This finding explains that individuals who are either positively or negatively or ambivalence toward critical thinking disposition were not depending at all on what fields they are attend. This finding coincide with previous research conducted by Giancarlo and Facione (2001), which reported that academic clusters did not differ significantly on analyticity, systematic and self-confidence subscales of the critical thinking disposition.

Table 2: Independent-sample-T-test on critical thinking disposition based on fields of study

\begin{tabular}{|c|c|c|c|c|c|c|}
\hline \multirow{2}{*}{ CTD Subscales } & \multicolumn{2}{|c|}{ Technical Science } & \multicolumn{2}{|c|}{ Social Science } & \multirow{2}{*}{$t$} & \multirow{2}{*}{$p$} \\
\hline & Mean & S.D. & Mean & S.D. & & \\
\hline Analyticity & 24.10 & 2.857 & 24.21 & 2.911 & -.260 & .795 \\
\hline Open-mindedness & 18.94 & 2.437 & 18.63 & 2.518 & .872 & .384 \\
\hline Maturity & 18.36 & 2.145 & 18.51 & 2.182 & -.446 & .656 \\
\hline Inquisitiveness & 22.22 & 2.489 & 22.44 & 2.760 & -.592 & .555 \\
\hline Truth-seeking & 24.19 & 2.056 & 24.45 & 2.154 & -.846 & .399 \\
\hline Systematic & 21.57 & 2.745 & 21.57 & 2.942 & .006 & .995 \\
\hline Self-confidence & 32.98 & 4.328 & 34.02 & 4.368 & -1.637 & .103 \\
\hline CTD (overall) & 162.36 & 13.552 & 163.83 & 13.938 & -.727 & .468 \\
\hline
\end{tabular}

\subsection{Correlation between subscales in passion in sport}

Table 3 showed the correlational results between harmonious passion, obsessive passion and passion (overall). Result indicated that passion (overall) showed positive strong significant correlation with these two subscales. Furthermore, this study also showed that obsessive passion has the positive moderate relationship with harmonious passion $(r=.371, p<$ .01) (Davis, 1971).

Table 3: Pearson's correlation ( $r$ ) between subscales in passion in sport

\begin{tabular}{|lccccc|}
\hline Passion Subscales & Mean & S.D. & $(1)$ & $(2)$ & $(3)$ \\
\hline (1) Harmonious passion & 29.28 & 3.866 & 1 & & \\
(2) Obsessive passion & 35.56 & 7.446 & $.371^{\star *}$ & 1 & \\
(3) Passion (overall) & 85.36 & 11.366 & $.753^{\star \star}$ & $.869^{\star \star}$ & 1 \\
\hline
\end{tabular}

${ }^{*} p<.05,{ }^{* *} p<.01$ 


\subsection{Correlation between subscales in critical thinking disposition}

Table 4 showed the correlational results of the seven subscales in critical thinking disposition. The findings indicated that all the subscales were significantly correlated with each other as interpreted by Pearson Correlation. The correlations were range between moderately correlated to strongly correlated (Davis, 1971).

Table 4: Pearson's correlation (r) between subscales in critical thinking disposition

\begin{tabular}{|c|c|c|c|c|c|c|c|c|c|c|}
\hline CTD Subscales & Mean & S.D. & (1) & (2) & (3) & (4) & (5) & (6) & (7) & (8) \\
\hline (1) Analyticity & 24.16 & 2.879 & 1 & & & & & & & \\
\hline (2) Open- mindedness & 18.78 & 2.478 & $.459^{\star \star}$ & 1 & & & & & & \\
\hline (3) Maturity & 18.44 & 2.160 & $.546^{\star *}$ & $.301^{\star *}$ & 1 & & & & & \\
\hline (4) Inquisitiveness & 22.34 & 2.631 & $.485^{\star \star}$ & $.579 * \star$ & $.386^{\star \star}$ & 1 & & & & \\
\hline (5) Truth-seeking & 24.33 & 2.107 & $.283^{\star \star}$ & $.180^{*}$ & $.314^{\star \star}$ & $.361^{\star \star}$ & 1 & & & \\
\hline (6) Systematic & 21.57 & 2.844 & $.439^{\star *}$ & $.341^{\star \star}$ & $.417^{\star \star}$ & $.408^{\star \star}$ & $.240^{\star \star}$ & 1 & & \\
\hline (7) Self-confidence & 33.53 & 4.369 & $.535^{\star \star}$ & $.455^{\star \star}$ & $.443^{\star \star}$ & $.465^{\star \star}$ & $.285^{\star \star}$ & $.379^{\star \star}$ & 1 & \\
\hline (8) CTD (overall) & 163.14 & 13.740 & $.775^{\star \star}$ & $.678^{\star \star}$ & $.675^{\star \star}$ & $.746^{\star \star}$ & $.504^{\star \star}$ & $.661^{\star \star}$ & $.793^{\star \star}$ & 1 \\
\hline
\end{tabular}

\subsection{Correlation between passion in sport and critical thinking disposition}

Table 5 presented the correlation between passion in sport and critical thinking disposition construct. The result interpreted that there was significant weak relationship (range $r=.180$ to .240 ) between the variables. The highest correlation was found between harmonious passion and critical thinking disposition (overall) with correlation, $r=.240, p<$ 0.01 . According to Vallerand et al. (2008), harmonious passion is conducive in enhancing the high levels of performance and encourages living in a happy life. Then, no surprise if harmonious passion inspires a person to be tendency toward critical thinking disposition. The finding indicates the lowest correlation was between harmonious passion with inquisitiveness $(r=.180, p<.05)$. However, harmonious passion showed no correlation with truth-seeking, systematic and maturity subscales. Also, there was no correlation between obsessive passion and critical thinking disposition's subscales. It is because individuals with obsessive passion are not completely in control of the activity. The previous studies (Vallerand et al., 2003; Vallerand, Rousseau, Grouzet, Dumais, Grenier, \& Blanchard, 2006) indicated obsessive passion was correlated with negative emotions during activity engagement and less reliably related to performance attainment and is unrelated to happiness. Similarly, no correlation found between passion (overall) and critical thinking disposition's subscales.

Table 5: Pearson's Correlation (r) between passion in sport and critical thinking disposition

\begin{tabular}{|lc|}
\hline Subscales & Harmonious passion \\
\hline Analyticity & $.221^{\star *}$ \\
Open-mindedness & $.236^{\star \star}$ \\
Inquisitiveness & $.180^{*}$ \\
CT-Self confidence & $.232^{\star *}$ \\
Truth-seeking & - \\
Systematic & - \\
Maturity & - \\
\hline CTD (overall) & $.240^{\star \star}$ \\
\hline$C T D=$ Critical Thinking Disposition, ${ }^{*} p<.05,{ }^{* *} p<.01$ &
\end{tabular}

\subsection{Regression of passion in sport towards critical thinking disposition}

Tables 6 presented only one subscale of passion "harmonious passion" was significantly influence in explaining critical thinking disposition accordingly. Based on data computed in Table 6, the value of adjusted R square .052 implied that the predictor variable (harmonious passion) explain $5.2 \%$ of overall disposition towards critical thinking. For each subscale, harmonious passion contributed $4.4 \%$ to analyticity, $5.1 \%$ to open-mindedness, $2.7 \%$ to inquisitiveness, and $4.9 \%$ to CT self-confidence. Hence, harmonious passion was proved to give the positively impact on critical thinking disposition 
based on present finding although with only weak effect. The harmonious passion enables control over the passionate activity, which contribute to the experience of positive affect and also reduce the experience of negative affect (Vallerand et al., 2008). In this perspective, harmonious passion let persons to participate in their passionate activity in a flexible manner because it is well integrated in the identity (Lafrenière et al., 2008). These findings are in accordance with the past research findings where harmonious passion has led to positive affective, cognitive, behavioral and relational outcomes (Mageau \& Vallerand, 2007; Vallerand et al., 2007). However, the present study was focus only on behavioral outcome underlying critical thinking disposition. Even no findings from past researches were support the impact of harmonious passion to critical thinking disposition but, researcher believed the existence of positive outcome since harmonious passion contributes to optimal functioning in reach high levels of performance then it will enable to give impact on development of critical thinking process.

For another passion predictor "obsessive passion" which was excluded because it does not contribute significantly to the variation in critical thinking disposition among athletes. In other words, obsessive passion leads to the experience of negative or fewer positive emotions and expected to be either unrelated or even negatively related to the quality of interpersonal behaviors (Vallarend et al., 2008; Lafrenière, Jowett, Vallerand, Donahue, \& Lorimer, 2008). Obsessive passion was occurring due to the internalization originates from intra and/or interpersonal pressure, either because certain contingencies are committed to the activity or because the sense of excitement resulting from activity engagement becomes overpowering, and therefore hard to regulate (Vallerand et al., 2008). This conclusion is thus in line with those of past research that obsessive passion was unbeneficial to relationships outside the passionate activity (Lafrenière et al., 2008).

Table 6: Regression analysis of passion in sport subscales towards critical thinking disposition

\begin{tabular}{|cccccc|}
\hline \multicolumn{5}{c|}{ Harmonious Passion } \\
\hline & Analyticity & Open-mindedness & Inquisitiveness & $\begin{array}{c}\text { CT-Self } \\
\text { confidence }\end{array}$ & CTD (Overall) \\
\hline Beta & $0.221^{* *}$ & $0.236^{\star \star}$ & $0.18^{\star}$ & $0.232^{\star *}$ & $0.24^{\star \star}$ \\
$\mathrm{t}$ & 3.077 & 3.304 & 2.488 & 3.242 & 3.362 \\
$p$ & 0.002 & 0.001 & 0.014 & 0.001 & 0.001 \\
$\mathrm{R}$ & .221 & .236 & .180 & .232 & .240 \\
$\mathrm{~F}$ & 9.467 & 10.917 & 6.192 & 10.513 & 11.304 \\
Adjusted & .044 & .051 & .027 & .049 & .052 \\
R Square & & & &
\end{tabular}

$C T D=$ Critical Thinking Disposition, ${ }^{*} p<.05,{ }^{*} p<.01$

\section{Concluding Remarks}

Basically, passion is referred as a strong tendency towards an activity that people like most to the extent where they invest a lot of time and energy. Passion was found to be a catalyst in providing the energy for persistent and strategic engagement in highly demanding activities. If people possess a harmonious passion in doing something, it is possible for them to sacrifice and put in all their effort including mastering critical thinking disposition to ensure they accomplish their goal. Hence, this explains a rationale in proposing athletes with strong desire are prone to be well knowledge in civil life. This study showed that there are positive and moderate correlation between obsessive passion and harmonious passion. There are also positive and moderate correlation between analyticity, open-mindedness, inquisitiveness and selfconfident with harmonious passion. This results can be emphasizes that athletes who are passionate in doing sport activity may be positively have tendency to dispose towards critical thinking. Finally, the passion was potentially affect critical thinking dispositions in athletes to ensure the great and success performance in sport arena.

\section{References}

Balon, S., Lecoq, J., \& Rimé, B. (2013). Passion and personality: Is passionate behavior a function of personality?. European Journal of Applied Psychology, 63, 59-65.

Bullen, M. (1998). Participation and critical thinking in online university distance education. Journal of Distance Education, 13 (2).

Deci, E. L., \& Ryan, R. M. (1985). Intrinsic motivation and self-determination in human behavior. New York, NY: Plenum.

Deci, E. L., \& Ryan, R. M. (2000). The "what" and "why" of goal pursuits: Human needs and the self-determination of behavior. Psychological Inquiry, 11, 227-268.

Deci, E. L., \& Ryan, R. M. (2008). Facilitating optimal motivation and psychological well-being across life's domains. Canadian 
Psychology, 49, 14-23.

Donahue, E. G., Rip, B., \& Vallerand, R.J. (2009). When winning is everything: On Passion, identity and aggression in sport. Journal Psychology of Sport and Exercise, 10, 526-534.

Duron, R., Limbach, B., Waugh, W. (2006). Critical Thinking Framework for Any Discipline. International Journal of Teaching and Learning in Higher Education, 17(1), 160-166.

Edmonds, M., Hull, J., Janik, E. \& Rylance, K. (2005). History and critical thinking: A handbook for using historical documents to improve students' thinking skills in the secondary grades. Madison: Wisconsin Historical Society.

El-Demerdash, D. A., Hawashy, Z.I. E., Donia, S. A. A. \& Taha, E. E. (2011). Preferred Educational Strategies and Critical Thinking Dispositions Among Nursing Students. Journal of American Science, 7(5). 406-416.

Emir, S. (2009). Education faculty student's critical thinking disposition according to academic achievement. Procedia Social and Behavioral Sciences, 1, 2466-2469.

Facione, N. C., \& Facione, P.A. (1997). Critical thinking assessment in Nursing Education Programs: An aggregate data analysis. Millbrae, CA: California Academic Press.

Facione, P. A. (1990). Critical thinking: A statement of expert consensus for purposes of educational assessment and instruction. Millbrae, CA: The California Academic Press.

Facione, P. A., (1998), Critical thinking: What it is and why it counts. [Online] Available: http://www.insightassessment.com/pdf_files/ what\&why98.pdf.

Facione, P. A., (2000), The disposition toward critical thinking: Its character, measurement and relationship to critical thinking skills. [Online] Available: http://www.insightassessment.com/CT-Resources/Independent-Critical-Thinking-Research/pdf-file/TheDisposition-Toward-Critical-Thinking-Its-Character-Measurement-and-Relationship-to-Critical-Thinking-Skill-PDF.

Facione, P. A., \& Facione, N. C. (1992). The California Critical Thinking Dispositions Inventory (CCTDI); and the CCTDI Test manual. Millbrae, CA: California Academic Press.

Facione, P. A., Facione, N. C., Blohm, S. W., Howard, K., \& Giancarlo, C. A. F. (1998). The California Critical Thinking Skills Test manual (Rev. Ed.). Millbrae, CA: California Academic Press.

Facione, P. A., Giancarlo, C. A., Noreen, C., Facione, N., \& Gainen, J. (1995). The disposition toward critical thinking. Journal of General Education, 44(1), 1-25.

Giancarlo, C. A., \& Facione, P. A. (2001). A Look across Four Years at the Disposition toward Critical Thinking among Undergraduate Students1. The Journal of General Education, 50(1), 29-55.

Halpern, D. F. (1998). Teaching critical thinking for transfer across domains: Disposition, skills, structure training, and metacognitive monitoring. American Psychologists, 53(4), 449-455.

Hodgins, H.S., \& Knee, R. (2002). The integrating self and conscious experience. In E.L. Deci \& R.M. Ryan (Eds.), Handbook on selfdetermination research (pp. 87-1000). Rochester, NY: University of Rochester Press.

Ibrahim Nazem Ghadi, Kamariah Abu Bakar, Nor Hayati Alwi, \& Othman Talib. (2013). Gender Analysis of Critical Thinking Disposition Instrument among University Putra Malaysia Undergraduate Students. Recent Technological Advances in Education, 27-30.

Kizlik, B., (2012), Thinking Skills Vocabulary and Definitions. [Online]Available: http://www.adprima.com/thinkskl.htm.

Kurfiss, J. G. (1988). Critical Thinking: Theory, Research, Practice, and Possibilities. ASHE-ERIC Higher Education Report No. 2.

Lafrenière, M-A. K., Jowett, S., Vallerand, R. J., Donahue, E. G., \& Lorimer, R. (2008). Passion in sport: On the Quality of Coach-Athlete Relationship. Journal of Sport and Exercise Psychology, 30, 541-560.

Linstead, S., \& Brewis, J. (2007). Passion, knowledge and motivation: Ontlogies of desire. Organization, 14(3), 351-371.

Mageau, G. A., Vallerand, R. J., Charest, J., Salvy, S-J., Lacaille, N., Bouffard, T., \& Richard, K. (2009). On development of harmonious and obsessive passion: The role of autonomy support, activity specialization, and identification with the activity. Journal of Personality, 77(3), 602-645.

Paul, R. W., Willson, J., \& Blinker, A. J. (1993). Critical thinking; what every person needs to survive in a rapidly changing world. Dillon Beach, CA: Foundation for Critical Thinking.

Profetto-Mcgrath, J. (2003). The relationship of critical thinking skills and critical thinking dispositions of baccalaureate nursing students. Journal of Advanced Nursing, 43(6), 569-577.

Ryan, R. M., \& Deci, E. L. (2007). Intrinsic and extrinsic motivation in exercise and sport. In M. S. Hagger \& N. L. D. Chatzisarantis (Eds.), Intrinsic motivation and self-determination in exercise and sport (pp. 1-20). Champaign, IL: Human Kinetics.

Som Hj. Nor \& Mohd Dahalan Mohd Ramli (1998). Kemahiran Berfikir Secara Kritis \& Kreatif (KBKK). Selangor: Longman Malaysia Sdn. Bhd.

Sormunen, C., \& Chalupa, M. (1994). Critical thinking skills research: Developing evaluation techniques. Journal of Education for Business, 69 (3), 172-178.

Qing, Z., Ni, S., \& Hong, T. (2010). Developing critical thinking disposition by task-based learning in chemistry experiment in teaching. Procedia Social and Behavioural Sciences, 2, 4561-4570.

Vallerand, R. J. (2010). On passion for life activities: The dualistic model of passion. In M. P. Zanna \& J. M. Olson (Eds.), Advances in experimental social psychology (pp. 97-133). San Diego, CA: Academic Press.

Vallerand, R. J., Blanchard, C., Mageau, G. A., Koestner, R., Ratella, C., Leonard, M. (2003). Les passions de l'ame: on obsessive and harmonious passion. Journal of Personality and Social Psychology, 85, 756-767.

Vallerand, R.J., Blanchard, C.M., Mageau, G.A., Koestner, R., Ratelle, C., Léonard, M., Gagné, M., \& Marsolais, J. (2003). Les passions de l'âme: On obsessive and harmonious passion. Journal of Personality and Social Psychology, 85, $756-76$. 
Vallerand, R. J., \& Houlfort, N. (2003). Passion at work. Emerging perspectives on values in organizations, Greenwich, CT: Information Age Publishing, 175-204.

Vallerand, R. J., \& Houlfort, N. (2003). Passion at work: Toward a new conceptualization. In S. W. Gilliland, D. D. Steiner, \& D. P. Skarlicki (Eds.), Emerging perspectives on values in organizations (pp. 175-204). Greenwich, CT: Information Age.

Vallerand, R. J., Mageau, G. A., Elliot, A. J., Dumais, A, Demers, M-A., \& Rousseau, F. (2008). Passion and performance attainment in sport. Psychology of Sport and Exercise, 9, 373-392.

Vallerand, R. J., \& Miquelon, P. (2007). Passion for sport in athletes. In D. Lavallee \& S. Jowett (Eds.), Social psychology in sports (pp. 249-262). Champaign, IL: Human Kinetics.

Vallerand, R. J., Rousseau, F. L., Grouzet, F. M. E., Dumais, A., Grenier, S., \& Blanchard, C. B. (2006). Passion in sport: A look at determinants and affective experiences. Journal of Sport \& Exercise Psychology, 28, 454-478.

Vallerand, R. J., Salvy, S. J., Mageau, G. A., Elliot, A. J., Denis, P. L., Grouzet, F. M., \& Blanchard, C. (2007). On the role of passion in performance. Journal of Personality, 75(3), 505-534.

Zhang, L-F. (2003). Contributions of thinking styles to critical thinking dispositions. Journal of Psychology, 137 (6), $517-543$. 